International Journal of Social Science and Economic Research

ISSN: 2455-8834

Volume:06, Issue:07 "July 2021"

\title{
A STUDY ON CUSTOMER SATISFACTION WITH REFERENCE TO MYNTRA
}

\author{
Ayush Tyagi \\ Bachelor of Business Administration, Guru Gobind Singh Indraprastha University, Delhi \\ DOI: 10.46609/IJSSER.2021.v06i07.014 URL: https://doi.org/10.46609/IJSSER.2021.v06i07.014
}

\begin{abstract}
Competing in a high-pressure business scenario has become a challenge for retailers. As an effective alternative, sales channel sellers are looking at the internet, which gives them direct access to target customers. Online retailing is a web-enabled interface between a retailer and its target consumers for selling products and services on the web with the facility of ecommerce. These kinds of retailers are also known as e-retailers. Myntra is one of them in themarket, holding a big share in the market. Almost all big retailers are now electronically present on the World Wide Web. The online shopping environment has gone through a lot of transformation and today it is still developing in a diversified way. Everybody in the world is the consumer. Each of us buys and sells or consumes goods and services in life. Consumer behavior is very complex and is determined to a large extent by social and psychological factors. Consumer behavior can be defined as those acts of individuals directly involved in obtaining, using and disposing of economic goods and services. The relevance and importance of understanding consumer behavior is rooted in modern marketing. The needs of not even two consumers are the same. Therefore, they buy only those products and services which satisfy their wants and desires. To survive in the market, a firm has to be constantly innovating and understanding the latest consumer needs and tastes. It will be extremely useful in exploiting marketing opportunities and in meeting the challenges that the Indian market offers. Myntra is a big player in online market and know its consumer base which helps it in getting more and more consumers. After collecting the data, I have reached the conclusion that customer is widely affected by four factors such as security, product availability, pricing, and delivery time. So company must ensure that these factors are managed efficiently. This study will be helpful for ecommerce companies as it also defines critical points that lead to dissatisfaction of consumers.
\end{abstract}

\section{INTRODUCTION}

Internet Marketing in its simplest terms refers to the marketing and selling of goods and services using the internet as the sales and distribution medium. The Internet has reduced the world into a 


\section{International Journal of Social Science and Economic Research}

ISSN: $2455-8834$

Volume:06, Issue:07 "July 2021"

global village, has made distance irrelevant and time zones little more than an inconvenience. Businesses in the remote parts of India can easily service clients in the bright cities of America, while goods produced in China are sold to consumers in all parts of the world. Internet Marketing offers anybody over a certainage with access to a computer and access to an Internet connection, the opportunity to go into business for themselves with little or no start-up costs. An online shop evokes the physical analogy of buying products or services at a regular "bricks-and-mortar" retailer or shopping center; the process is called business-to-consumer (B2C) online shopping. When an online store is set up to enable businesses to buy from another businesses, the process is called business-to-business (B2B) online shopping. A typicalonline store enables the customer to browse the firm's range of products and services, view photos or images of the products, along with information about the product specifications, features and prices.

India has an internet users based of about 450 million as of July 2017, 40\% of the population. Despite being the second-largest user base in world, there is less market share to market for online shopping portals. Its growth is at inflection point In India; cash on delivery is the most preferred payment method, as people have security issues while paying online. So the companies have launched new ideas to ease customer's life, where the customer can swipe card even on cash on delivery. The emergence of online shopping as we know today developed with the emergence of the Internet. Initially, this platform only functioned as an advertising tool for companies, providing information about its products. India has an internet users base of about 475 million as of July 2019 , about $40 \%$ of the population. This number is expected to be 627 million by the end of 2019.

\section{Company introduction}

Myntra is an Indian fashion e-commerce company headquartered in Bengaluru, Karnataka, India. The company was founded in 2007 to sell personalized gift items. Established by Mukesh Bansal along with Ashutosh Lawania and Vineet Saxena; Myntra sold on-demand personalized gift items. It mainly operated on the B2B (business-to-business) model during its initial years. Between 2007 and 2010, the site allowed customers to personalize products such as T-shirts, bags, computer covers, andothers.

2014: Myntra merged with Flipkart to compete against Amazon in the online space, as well as several offline retailers. Flipkart (and Myntra) were the market leaders in the online retail space in India, as of 2016. (Chanchani, 2016) Myntra won the title of "India's Most Admired \& Valuable Power Brand Award 2016" at the 7th Annual India Leadership Conclave \& Indian Affairs Business Leadership Awards 2016. Myntra's 2016 advertisement campaign with the tagline - "Try Myntra. You'll love it", aims to dispel the psychological barrier that consumers have about going digital - clothing items purchased through e-retailing portals as gifts don't 
International Journal of Social Science and Economic Research

ISSN: 2455-8834

Volume:06, Issue:07 "July 2021"

seem impressive or "good" enough. The Executive Creative Director of Taproot Denstu said that the brand had a problem - people were purchasing online, but had certain fears when it came to buyingclothes online. (Neogy, 2016) This campaign specifically targets these 80 million "offline consumers", who have such inhibitions and hence do not become Myntra's digital consumers for fashion related purchases. (Ramnath, 2016) To tackle further common psychological fears, Myntra also tries to provide a good customer experience with policies such as alteration, exchange, "Try and Buy", and "quality check at doorstep for returns". (Ganguly \& Shrivastava, 2016) Thus, Myntra effectively employs good advertising strategies coupled with customeroriented policies and offers, in order to ensure a favourable brand image. This works in its favour to convertmore offline consumers into digital consumers.

\section{Acquisitions}

In October 2007, Myntra received its initial funding from Erasmic Venture Fund (nowknown as Accel Partners), Sasha Mirchandani from Mumbai Angels and a few other investors. In November 2008, Myntra raised almost \$5 million from NEA-IndoUS Ventures, IDG Ventures and Accel Partners. Myntra raised \$14 million in a Series B round of funding. This round of investment was led by Tiger Global, a private equity firm; the existing investors IDG Ventures and Indo-US Venture Partners also put in substantial amount towards funding Myntra. Towards the end of 2011, Myntra.com raised \$20 million in its third round of funding, again led by Tiger Global. In February 2014, Myntra raised additional \$50 Million (Rs.310 crore) funding from Premji Investand few other Private Investors.

In 2015: Myntra acquired Bengaluru-based mobile app development platform company Native5, with a view to strengthen and expand Myntra's mobile technology team.

In 2016: Myntra acquired mobile-based content aggregation platform Cubeit, to strengthen and expand its technology team.

In July, 2016 Myntra acquired their rival Jabong.com to become India's largest fashionplatform. In October 2017, Myntra partnered with Ministry of Textiles to promote handloom industry.

In April 2017: The company acquired InLogg, a city-based technology platform that provides end-to-end logistics solutions for the e-commerce sector.

In April 2018: Myntra bought Bengaluru-based start-up Witworks, a maker of wearabledevices to strengthen its technology team.

\section{Digital Reality Show}


International Journal of Social Science and Economic Research

ISSN: 2455-8834

Volume:06, Issue:07 "July 2021"

Launched its first digital reality show "Myntra Fashion Superstar" which is based on the fashion influencer talent hunt on Myntra app on 17 September 2019. In association with Zoom Studios, this show will identify \& reward India's next big fashion influencer. Show has eight episodes of reality series which will see 10 contenders competing with each other. They would also be mentored and judged by a star studded jury, from the world of Bollywood, TV and fashion, including Bollywood diva Sonakshi Sinha and leading celebrity stylist, Shaleena Nathani.

\section{Industry overview}

\section{Introduction}

India has an internet users base of about 475 million as of July 2019, about $40 \%$ of the population. This number is expected to be 627 million by the end of 2019. Despite being the second-largest user base in world, only behind China (650 million, $48 \%$ of population), the penetration of e-commerce is low compared to markets like the United States (266 million, 84\%), or France (54 M, 81\%), but is growing, adding around 6 million new entrants every month. The industry consensus is that growth is at an inflection point.

In India, cash on delivery is the most preferred payment method, accumulating $75 \%$ ofthe e-retail activities. Demand for international consumer products (including long-tail items) is growing faster than in-country supply from authorised distributors and e- commerce offerings.

In 2017, the largest e-commerce companies in India were Flipkart, Amazon, Myntra, Paytm, and Snapdeal. In 2018, Amazon beat Flipkart and was recorded the biggest ecommerce in india in terms of revenue.

\section{Market size}

(a) 2009: India's e-commerce market was worth about \$3.9 billion in 2009.

(b) 2011: As per "India Goes Digital", a report by Avendus Capital, the Indian e- commerce market is estimated at Rs 28,500 Crore ( $\$ 6.3$ billion) for the year 2011. Online travel constitutes a sizable portion (87\%) of this market today. Online travelmarket in India had a growth rate of $22 \%$ over the next 4 years and reach Rs 54,800 crore ( $\$ 12.2$ billion) in size by 2015 . Indian e-tailing industry is estimated at Rs 3,600 crore (US\$800 million) in 2011 and estimated to grow to Rs 53,000 crore (\$11.8 billion) in 2015.

(c) 2013: The market went up to $\$ 12.6$ billion in 2013. In 2013, the e-retail segment was worth US\$2.3 billion. About $79 \%$ of India's e-commerce market was travel related in 2013. 
International Journal of Social Science and Economic Research

ISSN: 2455-8834

Volume:06, Issue:07 "July 2021"

(d) 2014: According to Google India, there were 35 million online shoppers in India in 2014 Q1 and was expected to cross 100 million mark by end of year 2016. CAGR vis-à-vis a global growth rate of 8-10\%. Electronics and Apparel are the biggest categories in terms of sales

(e) 2015: Overall e-commerce market had reached Rs 1,07,800 cores (US\$24 billion) by the year 2015 with both online travel and e-tailing contributing equally. Anotherbig segment in e-commerce is mobile/DTH recharge with nearly 1 million transactions daily by operator websites.

(f) 2016 also saw online sales of luxury products like jeweler also increased. Most of the retail brands have also started entering into the market and they expect at least $20 \%$ sales through online in next 2-3 years. According to Google India Research in 2016, by 2021 India is expected to generate $\$ 100$ billion online retail revenue out of which $\$ 35$ billion will be through fashion e-commerce.

(g) 2017: The ecommerce industry was reported at USD 24 billion in 2017 and was recognized as the fastest growing industry in India.

(h) 2018: The ecommerce market grew to USD 38.5 billion in 2018.

\section{Government initiatives}

Since 2014, the Government of India has announced various initiatives namely, Digital India, Make in India, Start-up India, Skill India and Innovation Fund. The timely and effective implementation of such programs will likely support the e-commerce growth in the country. Some of the major initiatives taken by the government to promote the e-commerce sector in India are as follows:

(a) Government e-Marketplace (GeM) signed a Memorandum of Understanding (MoU) with Union Bank of India to facilitate a cashless, paperless and transparent payment system for an array of services in October 2019.

(b) In February 2019, the Government of India released the Draft National e-Commerce Policy which encourages FDI in the marketplace model of e-commerce.

(c) In order to increase the participation of foreign players in the e-commerce field, the Indian Government hiked the limit of foreign direct investment (FDI) in the E- commerce marketplace model for up to 100 per cent (in B2B models). 
(d) The heavy investment of Government of India in rolling out the fiber network for $5 \mathrm{G}$ will help boost ecommerce in India

(e) In the Union Budget of 2018-19, government has allocated Rs 8,000 crore (US\$

(f) 1.24 billion) to BharatNet Project, to provide broadband services to 150,000 gram panchayats As of August 2018, the government is working on the second draft of ecommerce policy, incorporating inputs from various industry stakeholders.

\section{Objectives of the Study}

1.1.1 To study the case of internet marketing in Myntra.

1.1.2 To study the effectiveness of Myntra.

1.1.3 To study the reach of Myntra to the consumer.

1.1.4 To study about the customer satisfaction of online shopping at Myntra.

1.1.5 To study the consumers expectation and developments in online shopping.

\section{Scope of the Study}

1.2.1 To know there brand loyalty.

1.2.2 To know about which purchase type people prefer most.

1.2.3 To find out the reason for buying products.

1.2.4 To find out the price range that people prefer most.

1.2.5 To know which features they admire in their product.

\section{Research Methodology}

\section{Research design}

The Research Design Used for the Study. The research design used for the study is descriptive. Descriptive research studies are those, which are concerned with describing the characteristics of a particular individual or group. The studies concerned with specific prediction with narration of facts and characteristics concerning individual group or situation are all examples of descriptive research studies.

Method of data collection 
International Journal of Social Science and Economic Research

ISSN: 2455-8834

Volume:06, Issue:07 "July 2021"

The data is to be collected from primary sources and secondary sources:- Primary data

The data those are collected as fresh for first time and happen to be original in characterare called as primary data. Primary data collected with the help of questionnaire.

\section{Secondary Data}

Secondary data are collected from various sources, ie Internet, Books, Website, Company reports, Journals, Company profile.

\section{Hypothesis Testing}

H0.1 There is a no significant relationship between gender and opinion of serviceoffered by Myntra..

HO.2 There is a no significant relationship between Occupation Online Purchase atMyntra.

\section{Functional Area}

Marketing.

\section{Tools}

MS EXCEL, SPSS

\section{Literature review}

Vyas and Srinivas (2002), in their paper stated that majority of the internet users werehaving positive attitude towards online buying of products/services. There exists a need for developing awareness about consumers' rights and cyber laws. This study clarifies the relationship between school organization's internet marketing and teacher's organizational commitment by examining the mediating role of teachers' job involvement and job satisfaction. The importance of this study is to examine the customer satisfaction towards online shopping users in Coimbatore city. Also tried to find out various attributes of online shopping users for this survey was conducted. They also emphasized on better distribution system for online products. An inter-ministerial committee was constituted by Ministry of Electronics and Information Technology (MeitY) to discuss the issues related to online child sexual abuse materials (CSAM) and its blocking in India. Based on the recommendation of the committee and the approval of Humble Minister of Electronics and Information Technology, Ministory has issued an order dated. 18.04.2017 to Internet Service Providers(ISPs) to adopt and implement Internet Watch Foundation(IWF) resources on or before 31.07.2017 to prevent the distribution and transmission of Online CSAM into India. Recently at present time online shopping is the new trend of shopping in India that is 


\section{International Journal of Social Science and Economic Research}

ISSN: $2455-8834$

Volume:06, Issue:07 "July 2021"

used to refer to computer- based- shopping or E-shopping same like internet banking or Ebanking. Over the past few years online shopping or E- shopping has increased percentage of online buyer's in India. . The increasing use of internet by the young generation in India provides an emerging prospect for online retailers. In his paper said that traditional consumer behaviour shopping has its own model, which the buying process starts from the problem recognition, information search, evaluation of alternatives, then purchase, and at last post purchase behaviour. Although, there exist firewalls, antivirus software, and other technological solutions for safeguarding the data and computer networks, but in India much needs to be done towards effective use of these technologies for safeguarding the precious data and in combating cybercrime. Even most of the seasoned users of IT tools may not be aware of cyber victimization. Along with the advancementsin technology it is equally important to be aware of cybercrime and related issues thereof. The cyber safety depends on the knowledge of the technology and the care taken while using internet and that of the preventive measures adopted by user and servers systems. It is well said that the problems created cannot be solved with the samelevel of awareness that created them. Hence there is need to enhance awareness about the cybercrime. The growing danger by cybercrime in India needs technological, behavioral and legal awareness; and proper education and training. The study being reported herein examines the awareness of denizens about cyber laws and role of police.

As per Jayendra Sinha (2010) number of online activities is increasing day by day in terms of online shopping or booking train through internet. Number of people shoppingonline is increasing; it is not equivalent to that of brick-and mortar shoppers. There have many research conducted to explain the performance of online shopping compared to offline shopping. Reasons for not using online shopping portal is the risk of security for online transaction it depends on persons feedback(family or relatives) and limitations such as availability of Internet, computers, creditcards, cyber etc. Under the purview of aforementioned factors this study tried understanding the online shopping behavior of Indian consumers. Socio-psychological factors and limitation have been found influential factors security risk surprisingly is affecting less internet sale. The potential growth of online shopping has triggered the idea of conducting a study on online shopping in India. The present research paper has used Qualitative and Quantitative research methods to study the impact of Demographic factors of consumers on on-line shopping parameters like satisfaction with on-line shopping, future purchase intention, frequency of on-line shopping, numbers of items purchased, and overall spend on on- line shopping. The data was collected through Questionnaires. The results of study reveal that on-line shopping in India is significantly affected by various Demographic factors like age, gender, marital status, family size and income. The results of the studycould be further used by the researchers and practitioners for conducting future studiesin the similar area. 
International Journal of Social Science and Economic Research

ISSN: 2455-8834

Volume:06, Issue:07 "July 2021"

V.Kumar and Denish Shah 2011 have published research paper entitled "Pushing andPulling on the Internet "The internet is fast emerging as a domain sales channel. The Internet is expanding\& it influences consumer which shifts the consumer behaviour. It has changed the way product awareness, developed new modes of product consideration. These studies explain online shopping important and consumer buying behavior in online shopping. The internet has played a significant role in our daily life in that people can talk through the internet to one who is actually on the other side of the Earth, can send email around the clock, can search information, can play game withothers, and even can buy things online. Meanwhile, Internet shopping has been widely accepted as a way of purchasing products and services. Technology plays a vital role inimproving quality of the services provided by business; one of the technologies which really brought information revolution in society is internet technology. In this paper weintroduce the marketing concept and then consider its relationship to more recent concepts such as internet marketing, ecommerce and e-business. Marketing is an activity, set of institutions and process for creating, communicating, delivering and exchanging of the product. It involves all activities which associate with buying and selling of product or service. Even before the Internet there were many different ways to advertise, in different media such as radio, TV, newspapers, magazines, telemarketing and pamphlets. For promoting the product, the marketer should provide information to user about its product. Internet marketing (IM) is also known as digital marketing, web marketing, online marketing, or e-marketing. As the name suggest, it is the advertising of products or services over the Internet. However, it also implies marketing through the wireless media and through e-mail. Electronic customer relationship management (ECRM) systems are also categorized under Internet marketing. IM can be creative, as well as, technical through its design, development, advertising, and sales over the Internet. It facilitate new types of information based process for reaching and interacting with customers like online advertising, online ordertalking and online customer service etc.

T. Shenbhagavadivu , 2015 has published the article " A Study on Customer Satisfaction towards online shopping " focused on understanding the consumer's attitudes towards online shopping, making improvement in the factors that influence consumers to shop online and working on factors that affect consumers to shop online will help marketers to gain the competitive edge over others. Not only benefits but also risk is associated with online shopping. Generally speaking internet users avert online shopping because of credit-card fraud, lack of privacy, non-delivery risk, lack of guarantee of quality of goods and services. Concerned authorities are devising policiesto minimize the risk involved in e-business. As online shopping is a new medium so the consumer behavior in the field of online shopping is also pretty diverse in nature compare to traditional consumer behavior, so it is equally important for one to identify what factors influence consumers to shop online. In order to reach towards purchase decision, it consists of several factors which influence consumers to shop online. These factors are important 


\section{International Journal of Social Science and Economic Research}

ISSN: $2455-8834$

Volume:06, Issue:07 "July 2021"

for retailers to compete in the market and to make their product more compatible. Through electronic marketing and internet communication business firms are coordinating different marketing activities such as market research, product development, inform customers about product features, promotion, customer services, customer feedback and so on. Online shopping is used as a medium for communication and electronic commerce, it is to increase or improve in value, quality and attractivenessof delivering customer benefits and better satisfaction, that is why online shopping is more convenience and day by day increasing its popularity

Alam and Yasim (2010) reported that that website design, reliability, product variety and delivery performances are the four key factors influencing consumers' satisfaction of online shopping. Much research has been concentrating on customer satisfaction on online shopping in the world. However, there is still a need for closer examination on customer satisfaction in specific countries. Both established and new, large and small scale businesses are now using the Internet as a medium of sales of their products and services.

Adrita Goswami et.al (2013). Studied "Customer Satisfaction towards Online Shopping with Special Reference to Teenage Group of Jorhat Town" study concludes that online customers are satisfied. This research explicitly indicates that online marketer should give more importance on price factor and after sale factor. In this competition era all the online marketers should have to concentrate on the customer's satisfaction to retain the existing customers and have to offer new scheme day by day to attract the new customers.

Jayaprakash. K., Balakrishnan. N and Sivaraj. C (2016) examined the factors influencing online buying behavior of rural consumers towards online shopping. The following are the influencing factors with highest loading such as saving time and money, Follow as the new trend, Shopping at leisure time, Offers and seasonal discount, Easy to compare features and price; second factor by Wide range of products and Convenient Payment; third factor by Defective products are replaced properly and Aftersales services are satisfactory; and fourth factor by Free home delivery.

Jukariya and Singhvi (2018) analysed the key factors, which mostly affect the buyingbehaviours of students of MPUAT, Udaipur for online buying. The resercher identified that the following are the key factors such as Transaction security and multiple payment options, Privacy, Price and quality of the products, delivery time and after sales service were few major factors that affect students' online shopping behaviour. Mohanapriya and Anusuya (2014) carried out a research on, 'A study on Customer Preferences and Satisfaction towards Selected Online Websites with Special Reference to Coimbatore city', to find out the most preferred website among the selected websites, preference and level of satisfaction on online shopping. The study reveals that majority of the respondents prefer Flipkart followed by Amazon, eBay, Snapdeal, Jabong, Mytra. The 


\section{International Journal of Social Science and Economic Research}

ISSN: $2455-8834$

Volume:06, Issue:07 "July 2021"

customer prefers online purchase as it saves time, less price and due to convenience. Most of the respondents are satisfied with the service of online shopping such as timely delivery, discount offers, guarantee, warranty, and security.

Shanbhog et al. (2016) analysed customer's attitude towards direct selling and indirect selling online firms based on their reputation. The researcher concluded that customers prefer to use indirect selling of online firms mainly because of its offers, wide range of products, offering attractive discount or offers for every product and by displaying userreviews about the price and quality of the product. Purchased from their website, it helps in making buying decision.

Van et al. (2014) study entitled 'Evaluating Factors Influencing Consumer Satisfaction towards Online Shopping in Vietnam identified the factors that influence online shopping. The findings of the study reveal that the various factors that influence online shopping are merchandise attribute, payment method, security, privacy and customer service. ulti level marketing is a business form that originated in the United States during 1950's. From there onwards, network marketing companies have gained exceeding ground and have become widely spread and recognized, especially during the past ten years. Companies such as Tahitian Noni International, Herbal life, Ore flame, RCM, Mary Kay, Tupperware and Forever Living Products are all examples ofwell-known network marketing companies. Today 58 million people are involved in network marketing throughout the world and in 2006 the worldwide sales accounted for an estimated USD 109 billion. Multi-level marketing companies in many aspects are similar to any other type of company, they have customers, employees and sell goods or services and market their products. What makes network marketing companies unique is that their main asset is their distributors 'Independent Business Owners' (IBOs). Three segments were identified: value singularity, quality at any price, and reputation/recreation. The quality at any price and reputation/recreation segments were the predominant online shoppers. Although their orientations toward shopping differed, their behaviour, web site attribute ratings, and demographics were very similar except for occupation (managerial versus clerical, respectively). Besides revealing that the orientations of Indian consumers are not price-based, the relatively unfractionated factor analysis solutions for shopping orientations and web site dimensionality suggest that, in the emerging Indian economy, consumer conceptualizations of shopping have not yet undergone full elaboration. Thus, this cross-sectional study could be extended with longitudinal research to reveal how Indian consumers' perceptions of the marketplace change with market development and growing consumer sophistication.

\section{Data Analysis and Interpretation}

Q1) On the basis of age group. 
International Journal of Social Science and Economic Research

ISSN: 2455-8834

Volume:06, Issue:07 "July 2021"

Table no-3.1: Age group of respondents

\begin{tabular}{|c|c|c|}
\hline Group & Frequency & Percent \\
\hline $16-25$ & 49 & 72 \\
\hline $25-35$ & 11 & 16.2 \\
\hline $35-50$ & 8 & 11.8 \\
\hline Above 50 & 0 & 0 \\
\hline Total & 68 & 100 \\
\hline
\end{tabular}

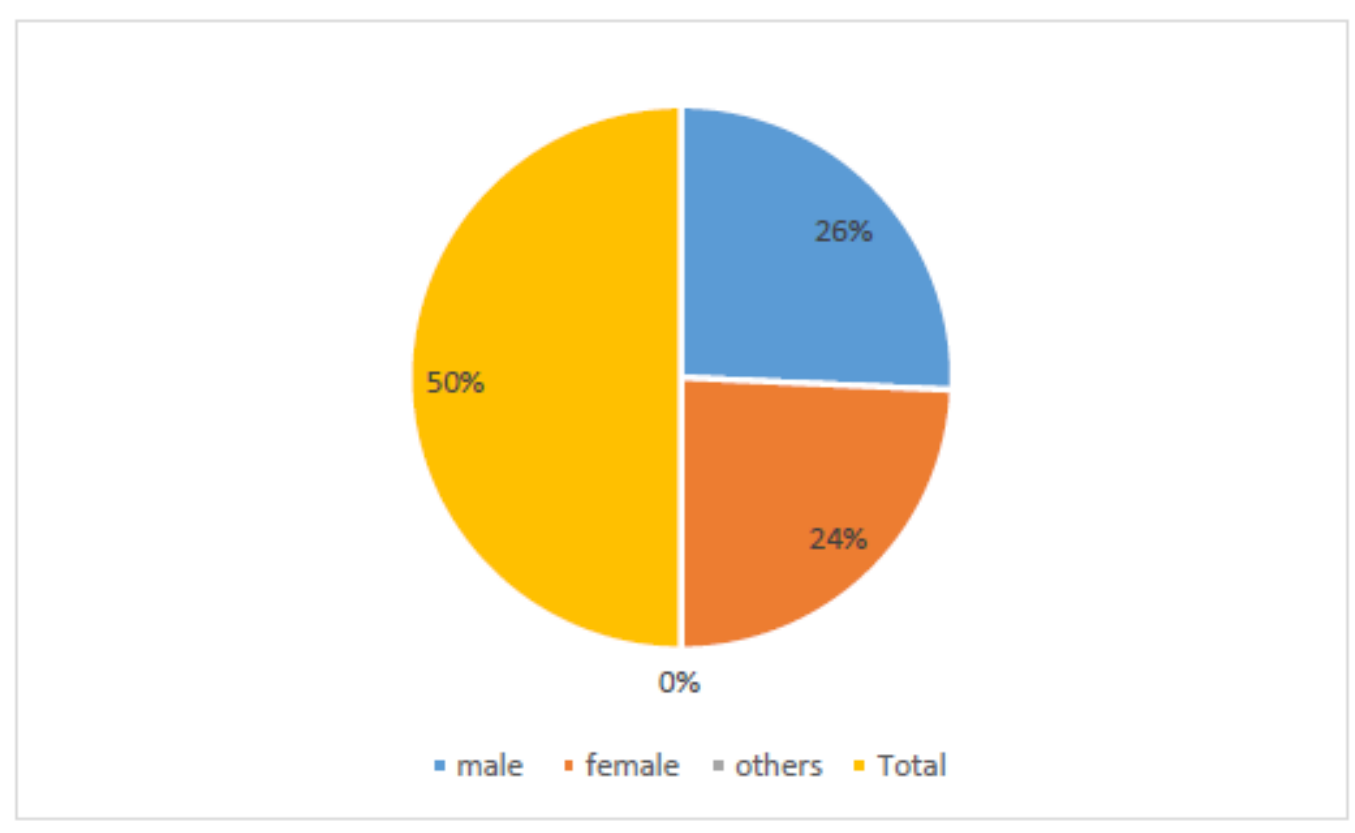

Figure no 3.1: Age group of respondents

Interpretation: - Among all 68 respondents, 49 respondents are from age group of 16-25 rest is from 25-35 and 35-50.

Q2) On the basis of gender 
International Journal of Social Science and Economic Research

Table no 3.2: Gender of the respondents

\begin{tabular}{|c|c|c|}
\hline Gender & Frequency & Percent \\
\hline Male & 33 & 51.5 \\
\hline Female & 35 & 48.5 \\
\hline Others & 0 & 0 \\
\hline Total & 68 & 100 \\
& & \\
\hline
\end{tabular}

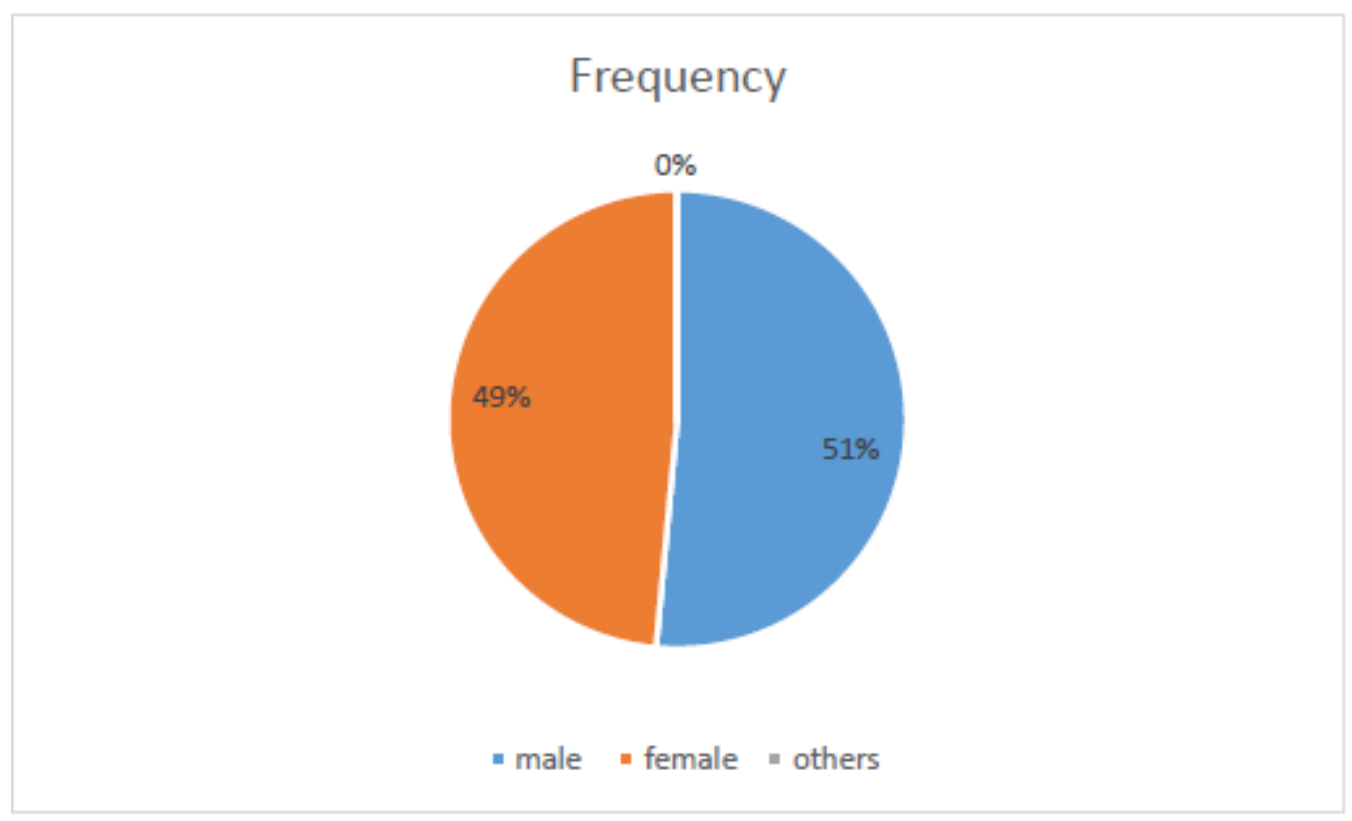

Figure no 3.2: Gender of the respondents

Interpretation: Among all 68 respondents, there were $51.00 \%$ males and $49.00 \%$ Females.

Q3) On the basis of occupation 
International Journal of Social Science and Economic Research

ISSN: 2455-8834

Volume:06, Issue:07 "July 2021"

Table no 3.3: Occupation of the respondents

\begin{tabular}{|l|l|l|}
\hline Occupation & Frequency & Percent \\
\hline Salaried & 6 & 8.8 \\
\hline Business & 11 & 16.2 \\
\hline Student & 49 & 72.1 \\
\hline Unskilled & 0 & 0 \\
\hline Others & 2 & 2.9 \\
\hline Total & 68 & 100 \\
\hline
\end{tabular}

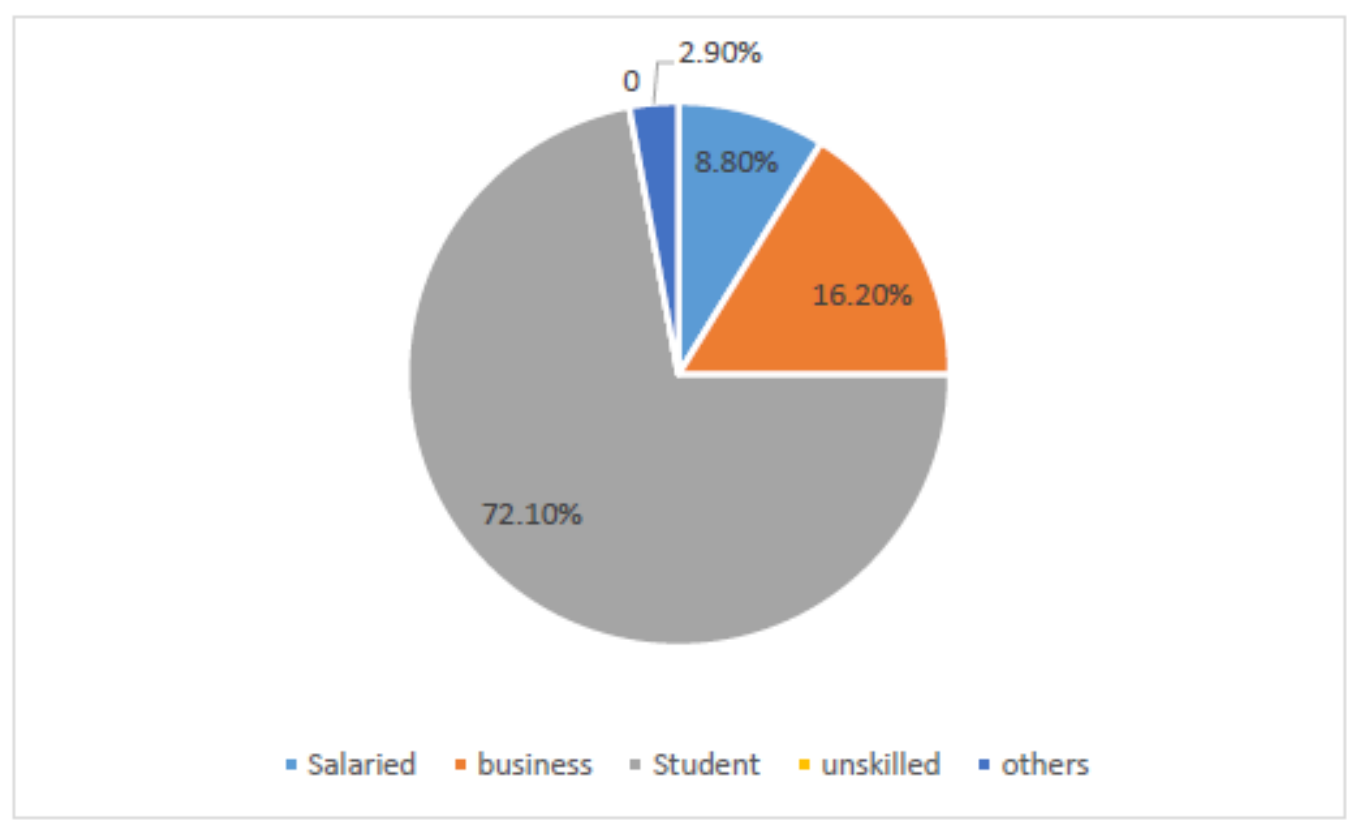

Figure no 3.3: Occupation of the respondents

Interpretation: Among all 68 respondents, there were $72.10 \%$ students, $16.20 \%$ unskilled respondents, $8.80 \%$ salaried respondents, and others are $2.90 \%$.

Q4) On the basis of income 
International Journal of Social Science and Economic Research

ISSN: 2455-8834

Volume:06, Issue:07 "July 2021"

Table no 3.4: Income group of the respondents

\begin{tabular}{|l|l|l|}
\hline Income Group & Frequency & Percent \\
\hline Less than 2 lakh rupees per annum & 35 & 51.5 \\
\hline 2-5 lakhs & 15 & 22.1 \\
\hline 5-8 lakhs & 12 & 17.6 \\
\hline 8-10 lakhs & 4 & 5.9 \\
\hline More than 10 lakhs per annum & 2 & 2.9 \\
\hline Total & 68 & 100 \\
\hline
\end{tabular}

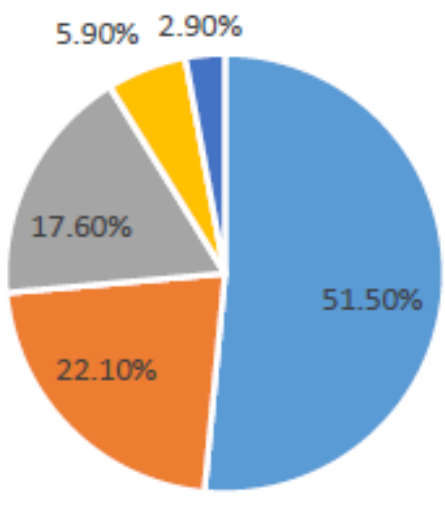

- less then 2 lakhs rupees per anum - 2-5 lakhs per anum

- 5-8 lakhs per anum

" 8-10 lakhs per anum

- more then 10 lakhs per anum

Figure no 3.4: Income group of the respondents

Interpretation: Among all 68 respondents, there were 51.50\% respondents less than 2 lakhs rupees per annum, $22.10 \%$ were from 2-5 lakhs per annum, 17.60\% from 5-8 lakhs, 5.9.\% respondents are from 8-10 lakhs per annum, On the basis ofeducation rest of them are more then 10 lakhs.

Q5) On the basis of education 
International Journal of Social Science and Economic Research

ISSN: 2455-8834

Volume:06, Issue:07 "July 2021"

Table no 3.5: Education of the respondents

\begin{tabular}{|l|l|l|}
\hline Education & Frequency & Percent \\
\hline Post Graduate & 17 & 25 \\
\hline Graduate & 38 & 55.9 \\
\hline School Student & 13 & 19.1 \\
\hline Total & 68 & 100 \\
\hline
\end{tabular}

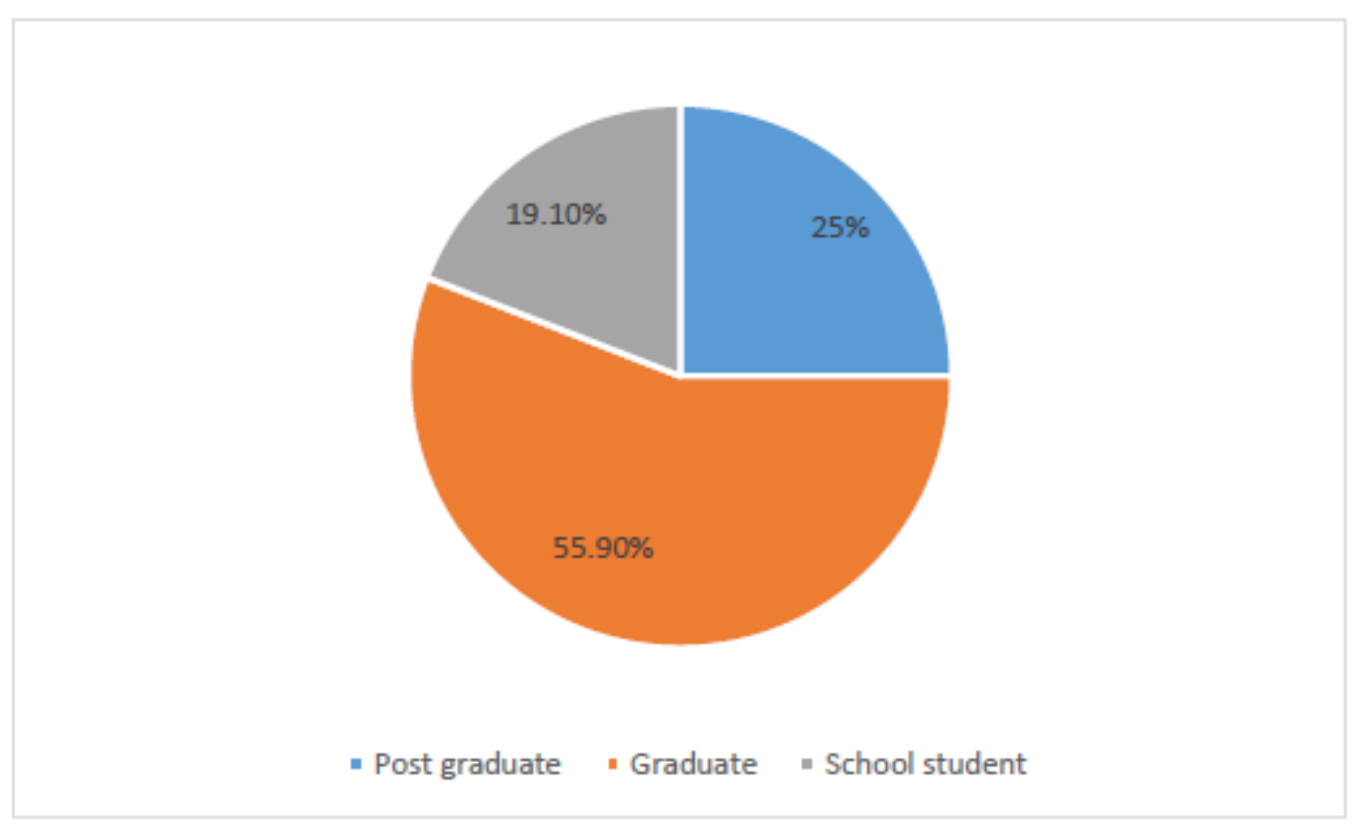

Figure no 3.5: Education of the respondents

Interpretation: Among all 68 respondents, there were 55.90\% respondents who fall Under graduate category, rest $25.00 \%$ falls under Post graduate and $19.10 \%$ of The respondents are the school students.

Q6) How often do you prefer to purchase online 
International Journal of Social Science and Economic Research

ISSN: $2455-8834$

Volume:06, Issue:07 "July 2021"

Table no 3.6: Prefer to purchase online

\begin{tabular}{|l|l|l|}
\hline Time Gap & Frequency & Percent \\
\hline Once a week & 7 & 10.3 \\
\hline Once in a month & 31 & 45.6 \\
\hline On festivals and occasions & 28 & 41.2 \\
\hline End of sales & 2 & 2.9 \\
\hline Total & 68 & 100 \\
\hline
\end{tabular}

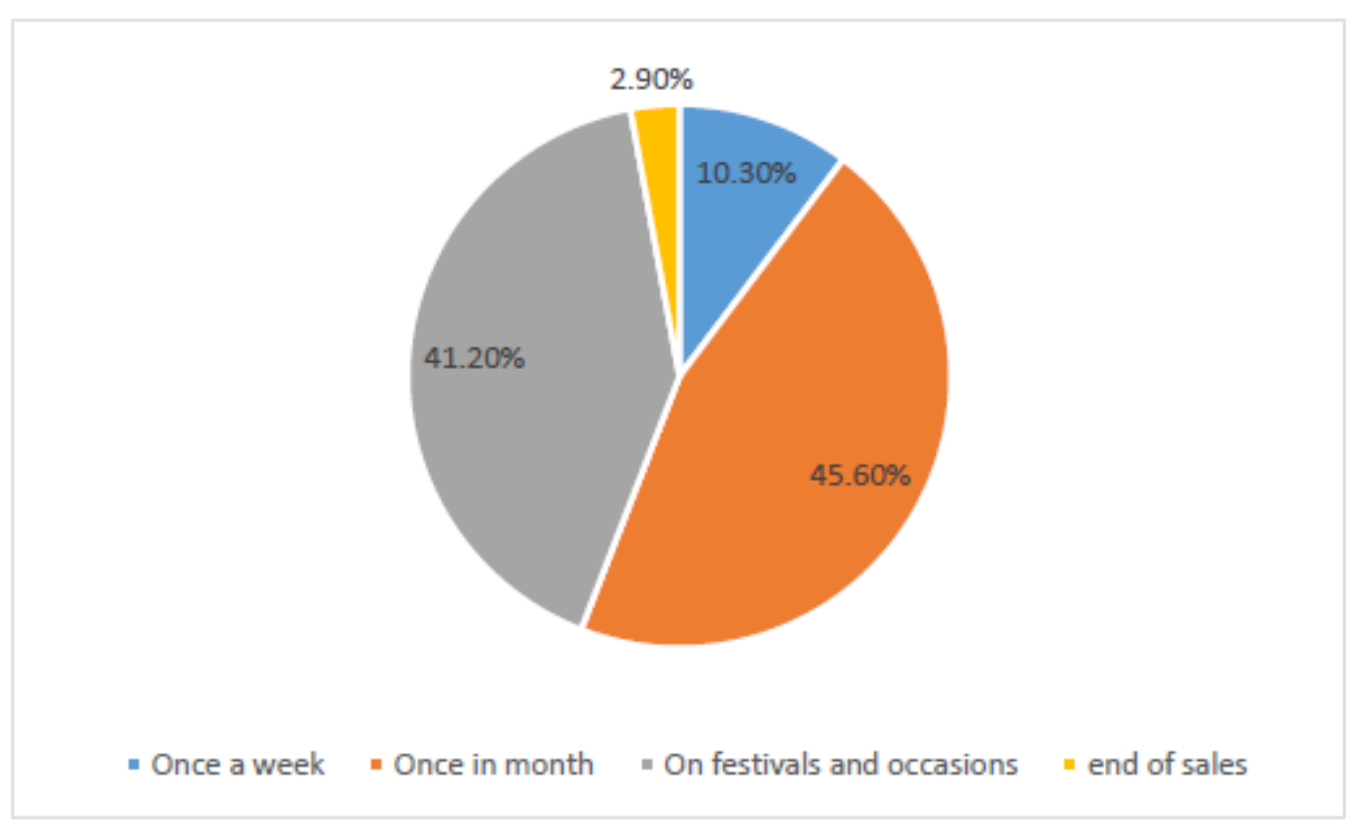

Figure no 3.6: Prefer to purchase online

Interpretation: Among all 68 respondents there were $45.60 \%$ respondents who Preferred to buy once a month, $41.20 \%$ respondents preferred to buy on festivals and occasions, $10.30 \%$ respondents preferred to buy once a week, and remaining $2.90 \%$ preferred to Buy in end of season sales.

Q7) Mode of payments available on myntra. 
International Journal of Social Science and Economic Research

ISSN: $2455-8834$

Volume:06, Issue:07 "July 2021"

Table no 3.7: payments available on myntra

\begin{tabular}{|c|c|c|}
\hline Payment mode & Frequency & Percent \\
\hline Debit Card & 27 & 39.7 \\
\hline Credit Card & 18 & 26.5 \\
\hline EMI & 7 & 10.3 \\
\hline Cash on Delivery & 38 & 55.9 \\
\hline Total & 68 & 100 \\
\hline
\end{tabular}

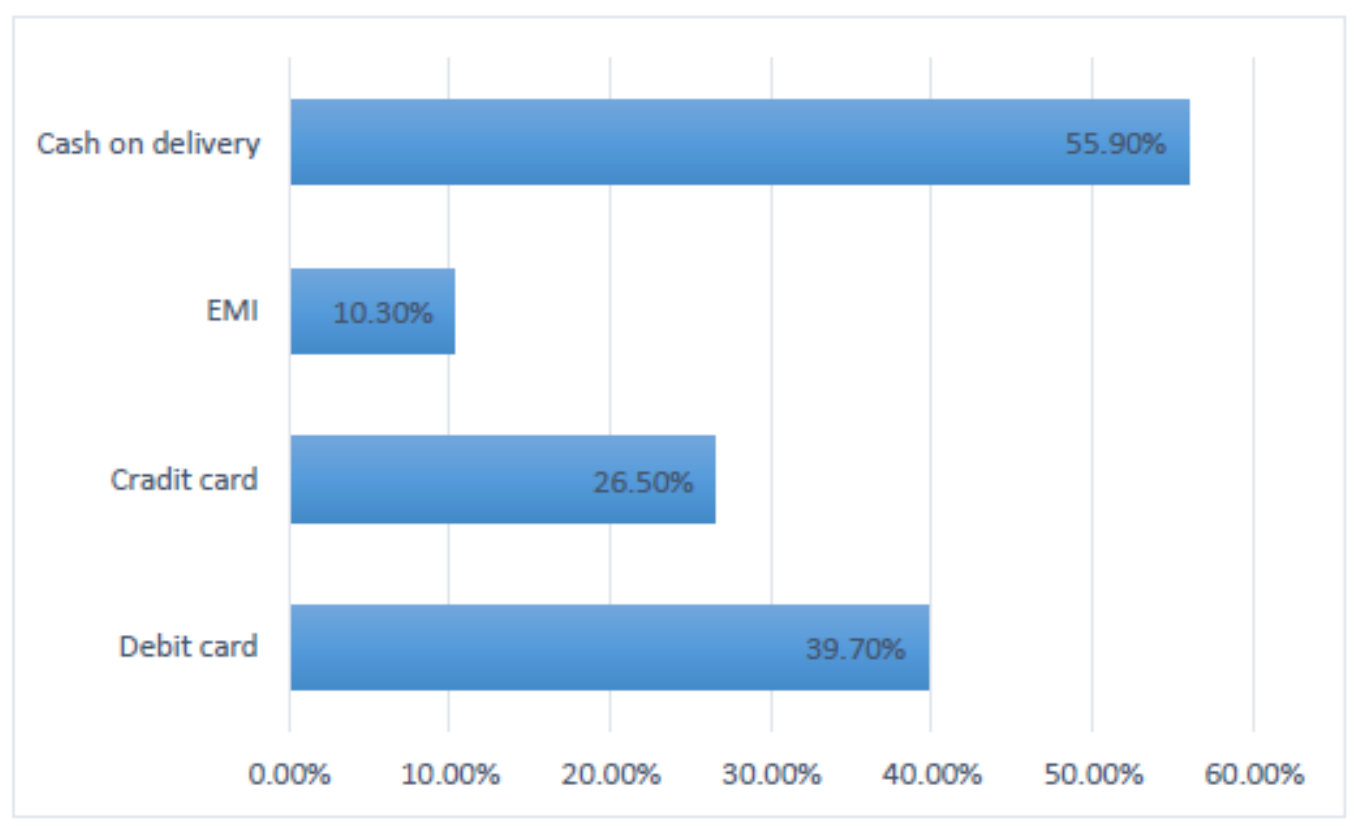

Figure no 3.7: payments available on myntra

Interpretation: Among all 68 respondents there were 55.90\% respondents who Preferred to use debits card as a payment mode, $20.00 \%$ preferred to use cash on Delivery, $24.00 \%$ preferred to use easy monthly instalments, $10.00 \%$ preferred to use Credit card as a payment mode.

Q8) How often do you buy shoes? 
International Journal of Social Science and Economic Research

ISSN: 2455-8834

Volume:06, Issue:07 "July 2021"

Table no 3.8: How often do you buy shoes

\begin{tabular}{|l|l|l|}
\hline Buy Shoes & Frequency & Percent \\
\hline Several times per month & 3 & 4.4 \\
\hline Once per month & 21 & 30.9 \\
\hline Once every six months & 26 & 38.2 \\
\hline Once per year & 18 & 26.5 \\
\hline Total & 68 & 100 \\
\hline
\end{tabular}

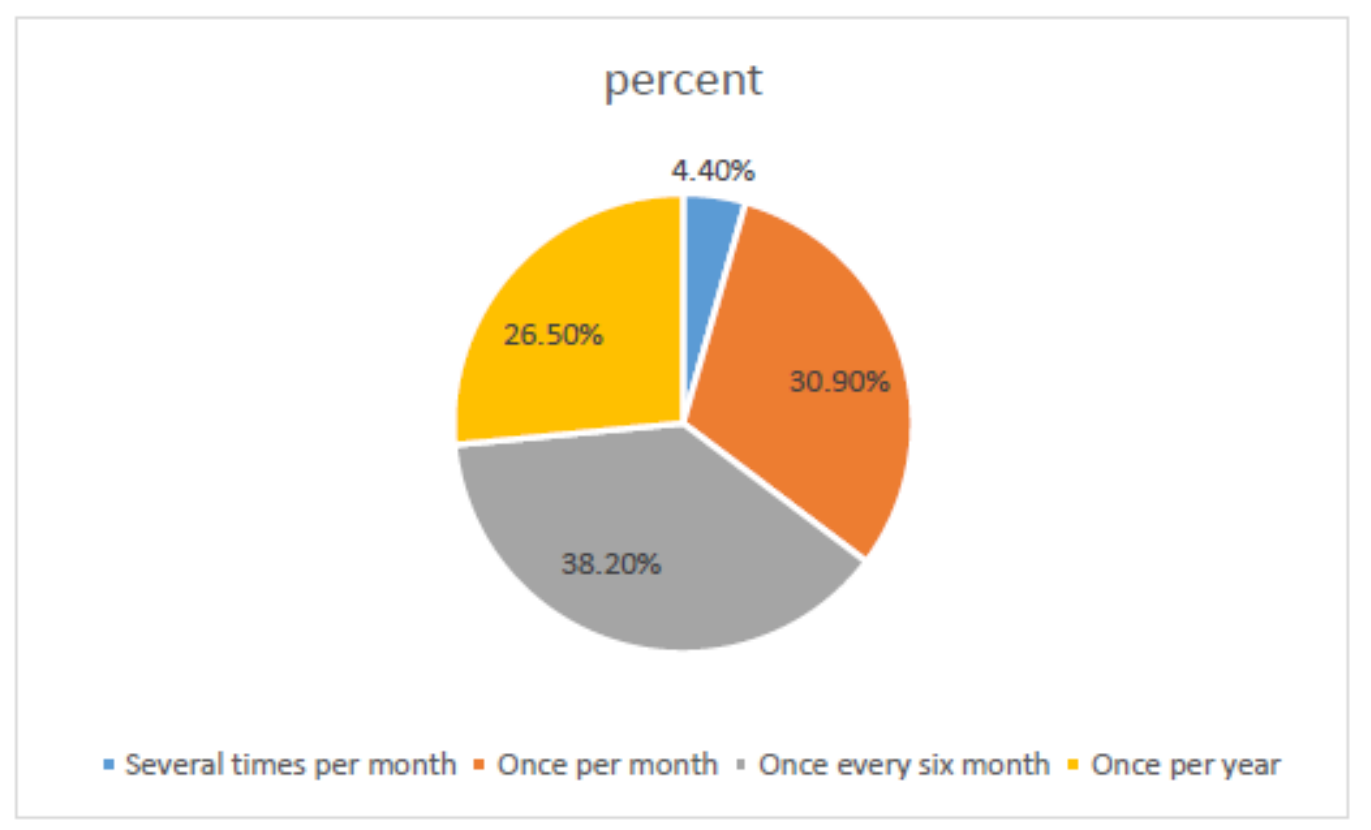

Figure no 3.8: How often do you buy shoes

Interpretation: Among all 68 respondents there were $38.20 \%$ who purchases once every six month, $30.90 \%$ are those who purchases once per month, $26.50 \%$ are those who purchases shoes once every year, but there some of those who purchases shoes several times per month.

Q9) Do you follow current fashion trends? 
International Journal of Social Science and Economic Research

ISSN: 2455-8834

Volume:06, Issue:07 "July 2021"

Table no 3.9: follow current fashion trends

\begin{tabular}{|l|l|l|}
\hline Follow fashion trends & Frequency & Percent \\
\hline Yes, I follow them closely & 28 & 41.2 \\
\hline Yes, but I really don't follow them & 27 & 39.7 \\
\hline No & 13 & 19 \\
\hline Total & 68 & 100 \\
\hline
\end{tabular}

\section{percent}

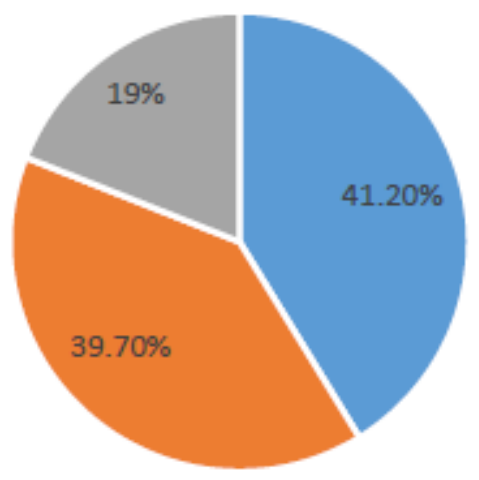

- yes, I follow them closely - yes, but I really don't follow them = no

\section{Figure no 3.9: follow current fashion trends}

Interpretation: Among all 68 respondents there were $41.20 \%$ who sees but not really follow them, $39.70 \%$ are those who follows really closely, $19.00 \%$ are those who don'tfollow the current fashion trend.

Q10) How much do you spent on clothing per year? 
International Journal of Social Science and Economic Research

ISSN: 2455-8834

Volume:06, Issue:07 "July 2021"

Table no 3.10- how much do you spend on clothing per year

\begin{tabular}{|l|l|l|}
\hline Spending per year & Frequency & Percent \\
\hline Rs. 100-600 & 2 & 2.9 \\
\hline Rs. 600-1200 & 14 & 20.6 \\
\hline Rs. 1200-2000 & 20 & 29.4 \\
\hline Rs. 2000-5000 & 13 & 19.1 \\
\hline Rs. 5000 or more & 19 & 27.9 \\
\hline Total & 68 & 100 \\
& &
\end{tabular}

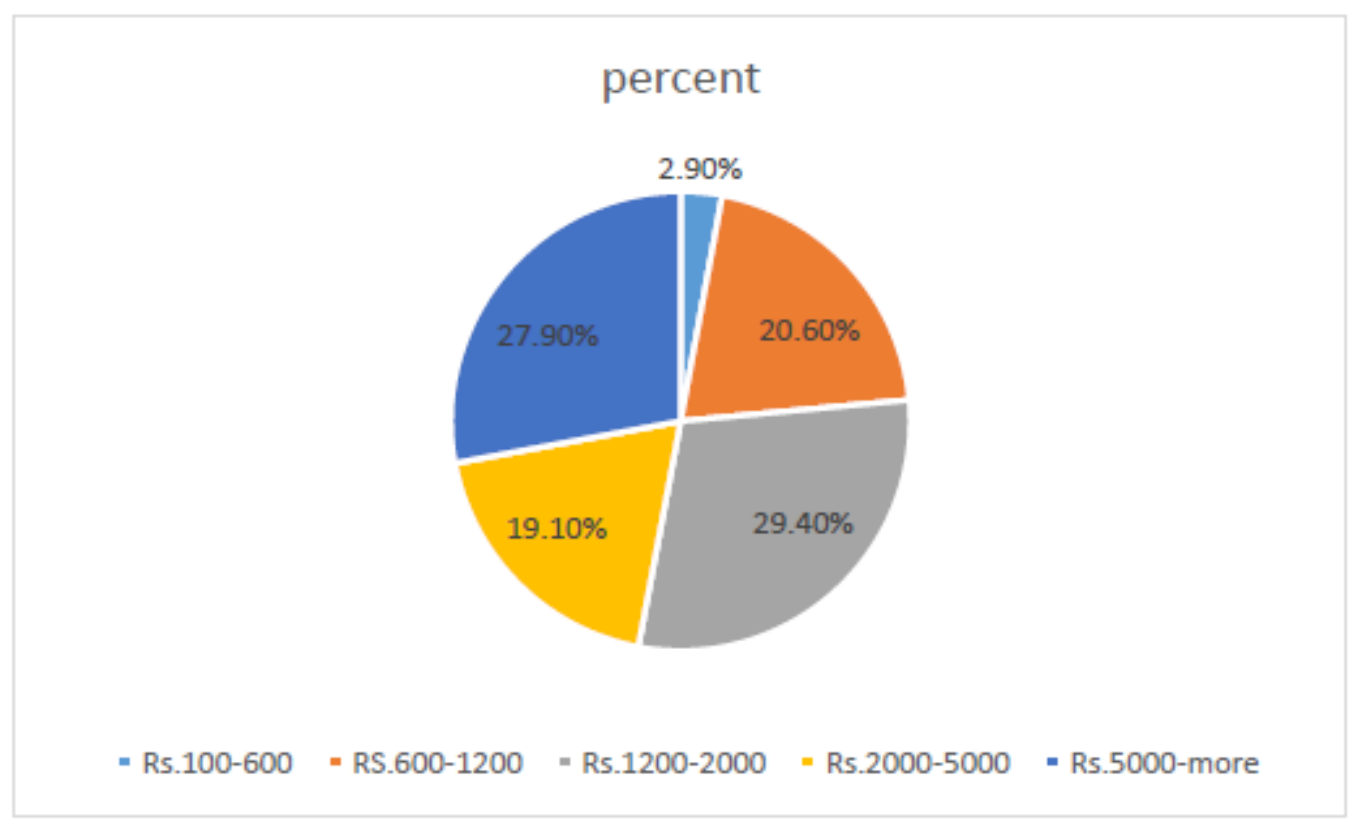

Figure no 3.10 how much do you spend on clothing per year

Interpretation: Among all 68 respondents, there were 27.90\% who spends Rs.100-600per year, $29.40 \%$ are those respondents who spend 1200-2000 per year, $20.60 \%$ are those respondents who spends RS.600-1200 per year, 19.10\% are those recipients who spends Rs.2000-5000 per year and some of the recipients are there who spends more than Rs 5000.

Q11) Myntra prides proper images, dimension to the customers and proper details? 
International Journal of Social Science and Economic Research

ISSN: 2455-8834

Volume:06, Issue:07 "July 2021"

Table no 3.11-prides proper images, dimension to the customers and properdetails

\begin{tabular}{|l|l|l|}
\hline Provide proper information & Frequency & Percent \\
\hline Yes & 51 & 75 \\
\hline No & 17 & 25 \\
\hline Total & 68 & 100 \\
\hline
\end{tabular}

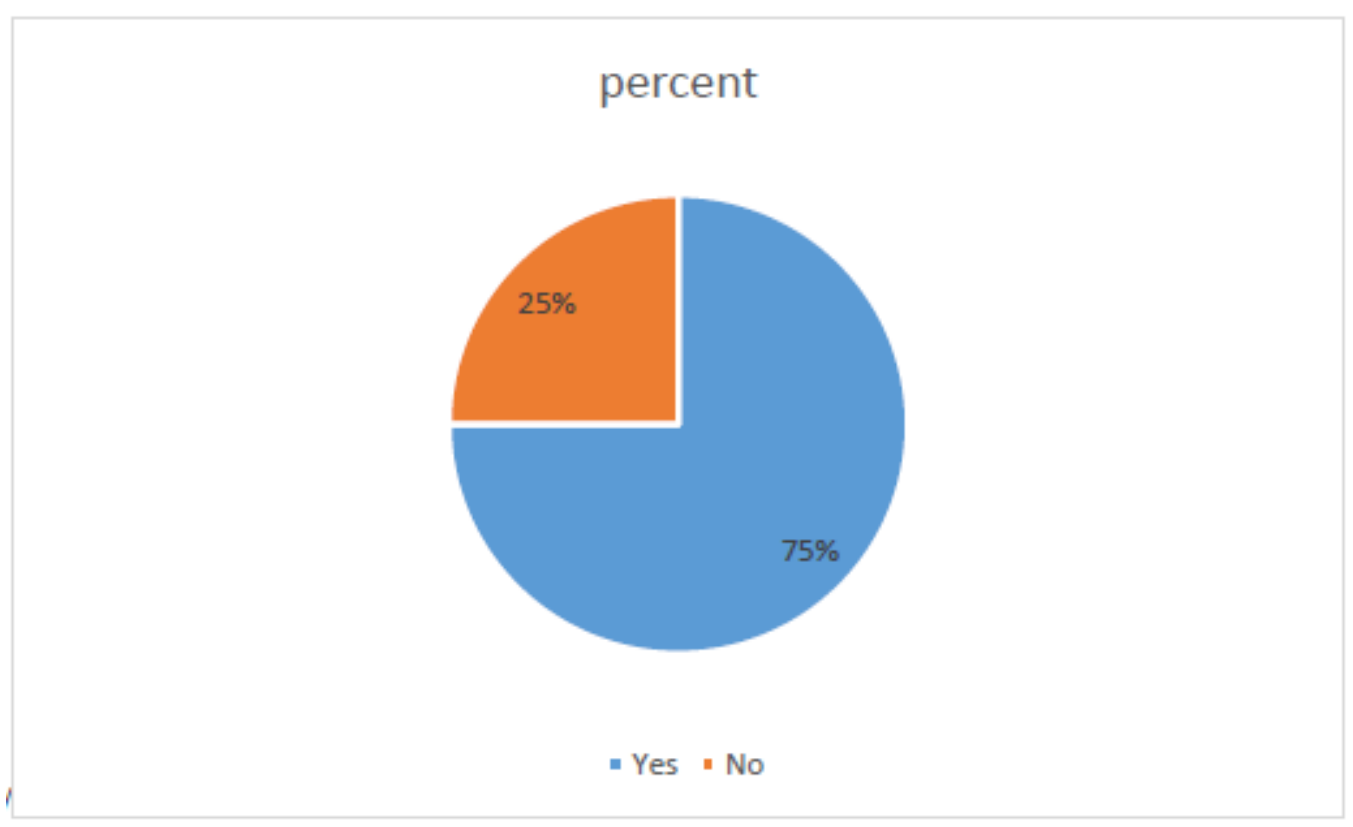

Figure no 3.11-prides proper images, dimension to the customers and properdetails

Interpretation: $75 \%$ of the recipients are in favour of the statement that myntra provides proper images, dimension to the customers and proper details but there are $25 \%$ of the recipients who don't agree with this statement.

Q12) Is myntra good for clothing in e-commerce?

Table no 3.12- Is myntra good for clothing in e-commerce

\begin{tabular}{|c|l|l|}
\hline $\begin{array}{c}\text { Good for } \\
\text { clothing }\end{array}$ & Frequency & Percent \\
\hline Yes & 60 & 88.2 \\
\hline
\end{tabular}


International Journal of Social Science and Economic Research

ISSN: $2455-8834$

Volume:06, Issue:07 "July 2021"

\begin{tabular}{|c|l|l|}
\hline No & 8 & 11.8 \\
\hline Total & 68 & 100 \\
\hline
\end{tabular}

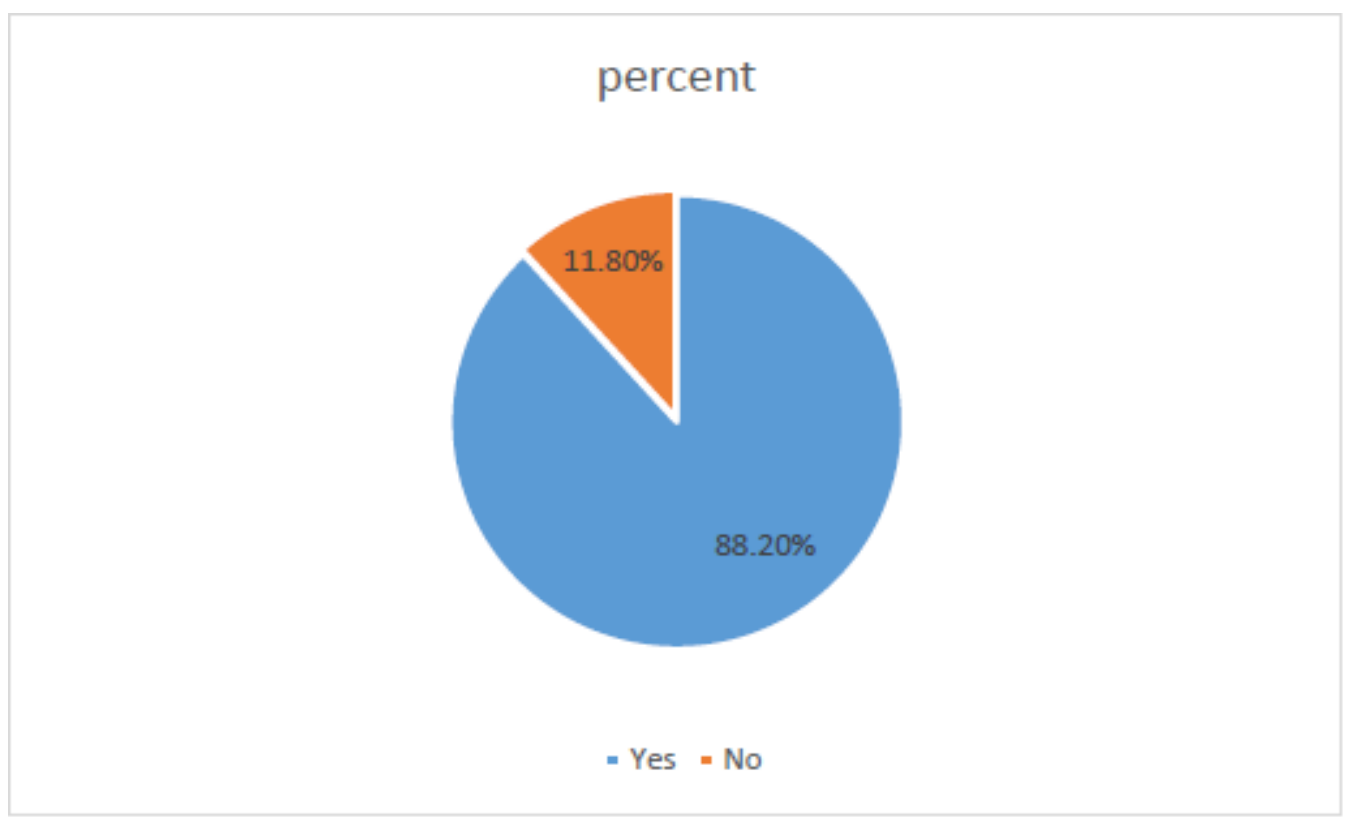

Figure no 3.12: Is myntra good for clothing in e-commerce

Interpretation: $88.20 \%$ of the recipients are in favour of the statement that myntra is good for clothing in e-commerce, but there are $11.80 \%$ of the recipients who don't agreewith this statement. Q13) Myntra provides the best after sales services?

Table no 3.13: provides the best after sales services

\begin{tabular}{|l|l|l|}
\hline After Sales Service & Frequency & Percent \\
\hline Sometimes & 13 & 19.1 \\
\hline Every time & 32 & 47.1 \\
\hline Depends on situation & 23 & 33.8 \\
\hline Never & 0 & 0 \\
\hline Total & 68 & 100 \\
\hline
\end{tabular}




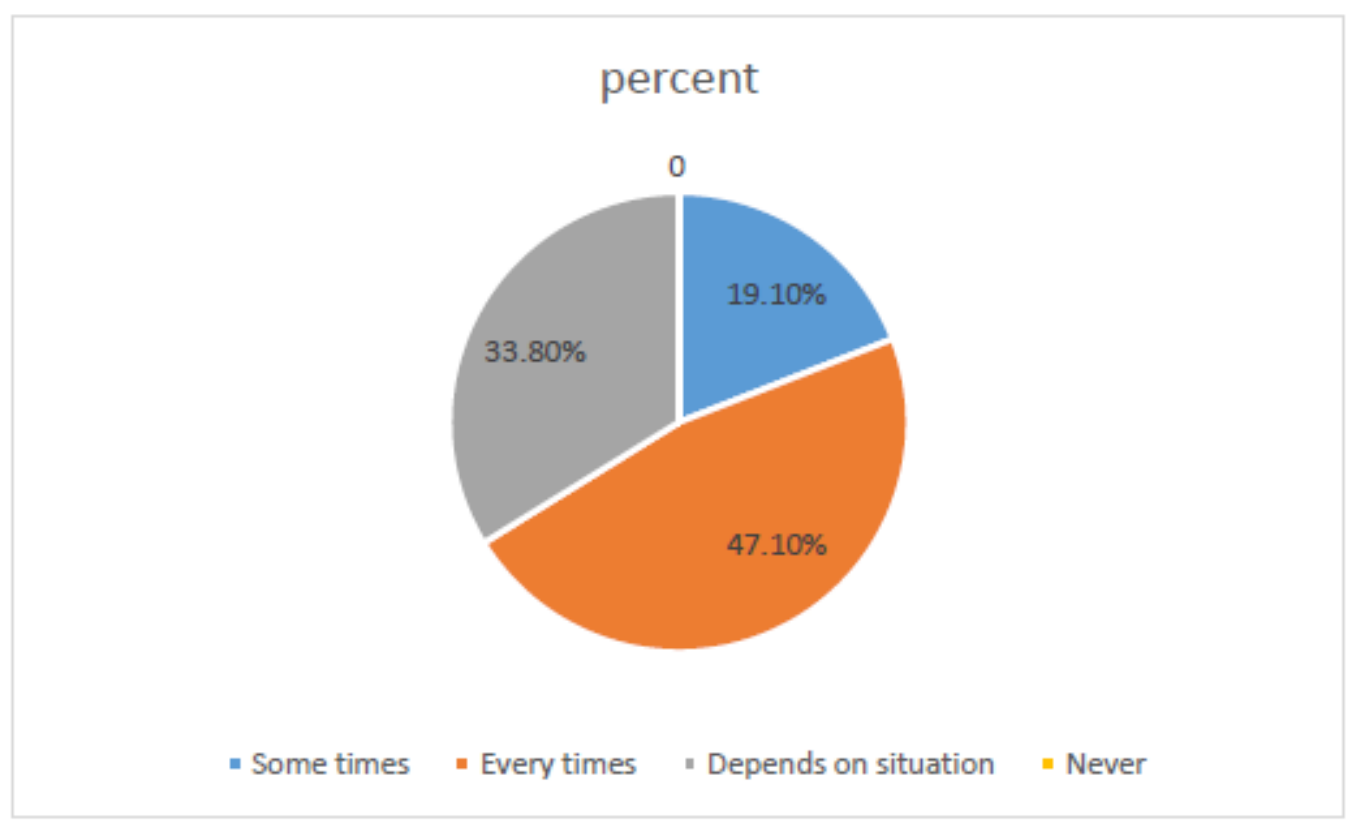

\section{Figure no 3.13: provides the best after sales services}

Interpretation: Among all 68 respondents there were $47.10 \%$ of respondents says that myntra provides best sales services every time, $33.80 \%$ respondents says sales servicesof myntra depends on situation, $19.10 \%$ of respondents says that myntra provides bestsales services some times.

Q14) Is myntra good for branded clothing?

Table no 3.14: Is myntra good for branded clothing

\begin{tabular}{|l|l|l|}
\hline Branded Clothing & Frequency & Percent \\
\hline Agree & 57 & 83.80 \\
\hline Disagree & 11 & 16.20 \\
\hline Total & 68 & 100 \\
\hline
\end{tabular}


International Journal of Social Science and Economic Research

ISSN: 2455-8834

Volume:06, Issue:07 "July 2021"

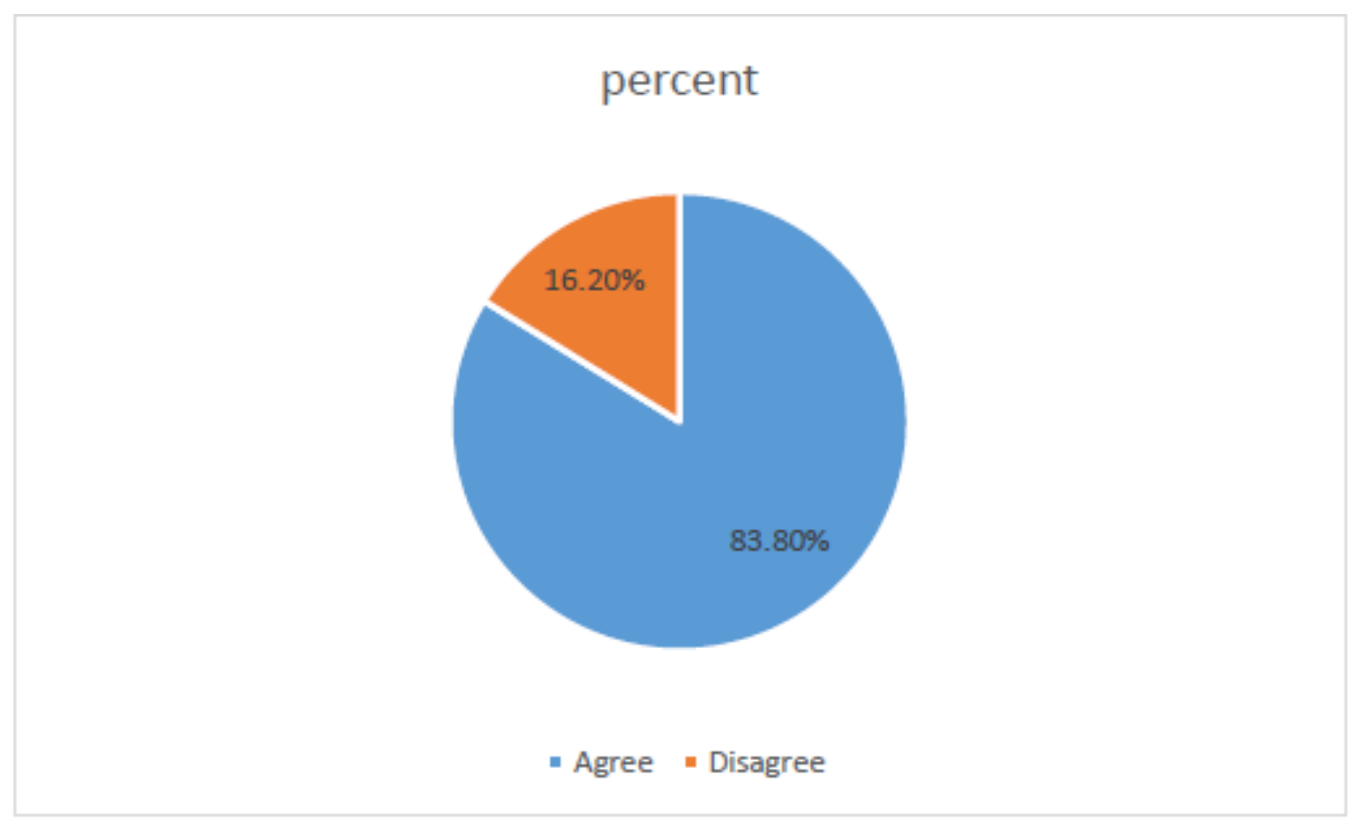

Figure no 3.14: Is myntra good for branded clothing

Interpretation: $83.80 \%$ of the recipients are in favour of the statement that myntra is good for branded clothing, but there are $16.20 \%$ of the recipients who don't agree withthis statement.

Q15) How do you rate your overall myntra experience?

Table no 3.15: rate your overall myntra experience

\begin{tabular}{|l|l|l|}
\hline Overall Experience & Frequency & Percent \\
\hline Poor & 1 & 1.50 \\
\hline Average & 16 & 23.50 \\
\hline Good & 29 & 42.60 \\
\hline Very Good & 14 & 20.60 \\
\hline Excellent & 8 & 11.80 \\
\hline Not Applicable & 0 & 0 \\
\hline Total & 68 & 100 \\
\hline
\end{tabular}




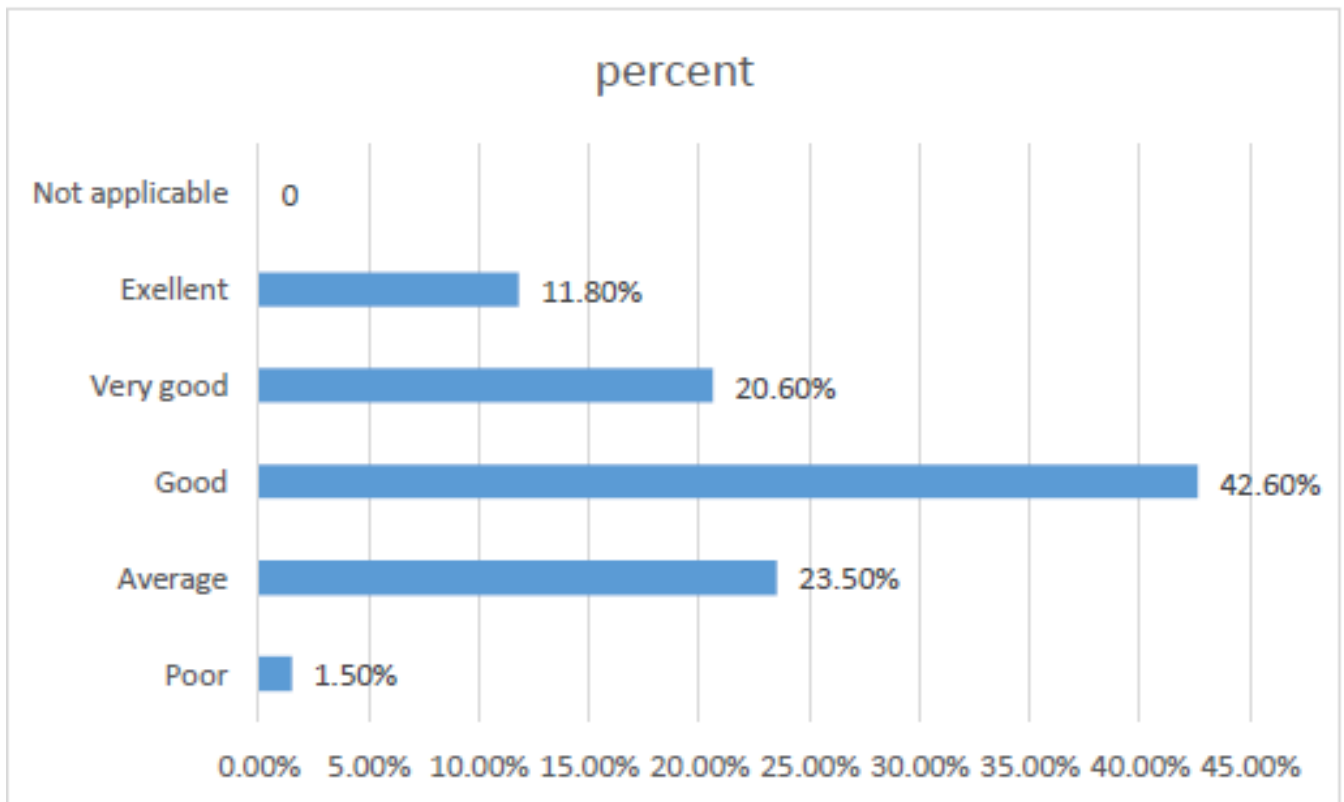

Figure no 3.15: rate your overall myntra experience

Interpretation: : Among all 68 respondents there were $42.60 \%$ of respondents says that the overall experience of myntra is good, $23.50 \%$ respondents says that the overall experience of myntra is average, $20.60 \%$ of respondents says that myntra's experience is very good. there are $11.80 \%$ of respondents that says that myntra's experience is excellent but there are $1.50 \%$ of the respondents, says it poor.

Q16) Does myntra have wide variety of fashionable items?

Table no 3.16: Does myntra have wide variety of fashionable items

\begin{tabular}{|l|l|l|}
\hline Variety & Frequency & Percent \\
\hline Strongly Disagree & 4 & 5.90 \\
\hline Disagree & 8 & 11.80 \\
\hline Neutral & 23 & 33.80 \\
\hline Agree & 26 & 38.20 \\
\hline Strongly Agree & 7 & 10.30 \\
\hline Total & 68 & 100 \\
\hline
\end{tabular}




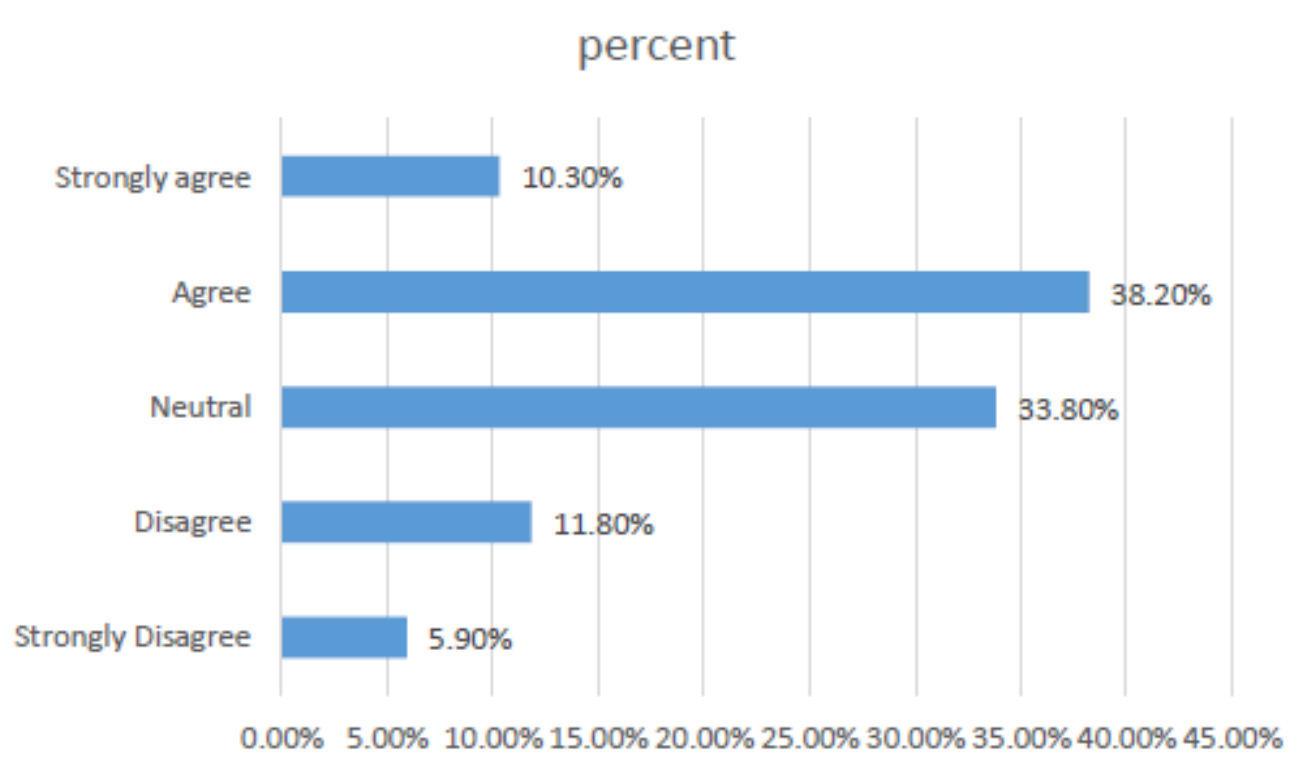

Figure no 3.16: Does myntra have wide variety of fashionable items

Interpretation: Among all 68 respondents there were $10.30 \%$ respondents who strongly agreed that myntra have wide variety of fashionable items, $38.20 \%$ respondents said Agree, $33.80 \%$ said neutral, $11.80 \%$ were disagree and $5.90 \%$ were strongly disagree.

Q17) Myntra is flexible in terms of return and refund policy.

Table no 3.17: flexible in terms of return and refund policy.

\begin{tabular}{|l|l|l|}
\hline Flexible in return policy & Frequency & Percent \\
\hline Strongly Disagree & 2 & 2.90 \\
\hline Disagree & 10 & 14.70 \\
\hline Neutral & 18 & 26.50 \\
\hline Agree & 32 & 47.10 \\
\hline Strongly Agree & 6 & 8.80 \\
\hline Total & 68 & 100 \\
\hline
\end{tabular}


International Journal of Social Science and Economic Research

ISSN: 2455-8834

Volume:06, Issue:07 "July 2021"

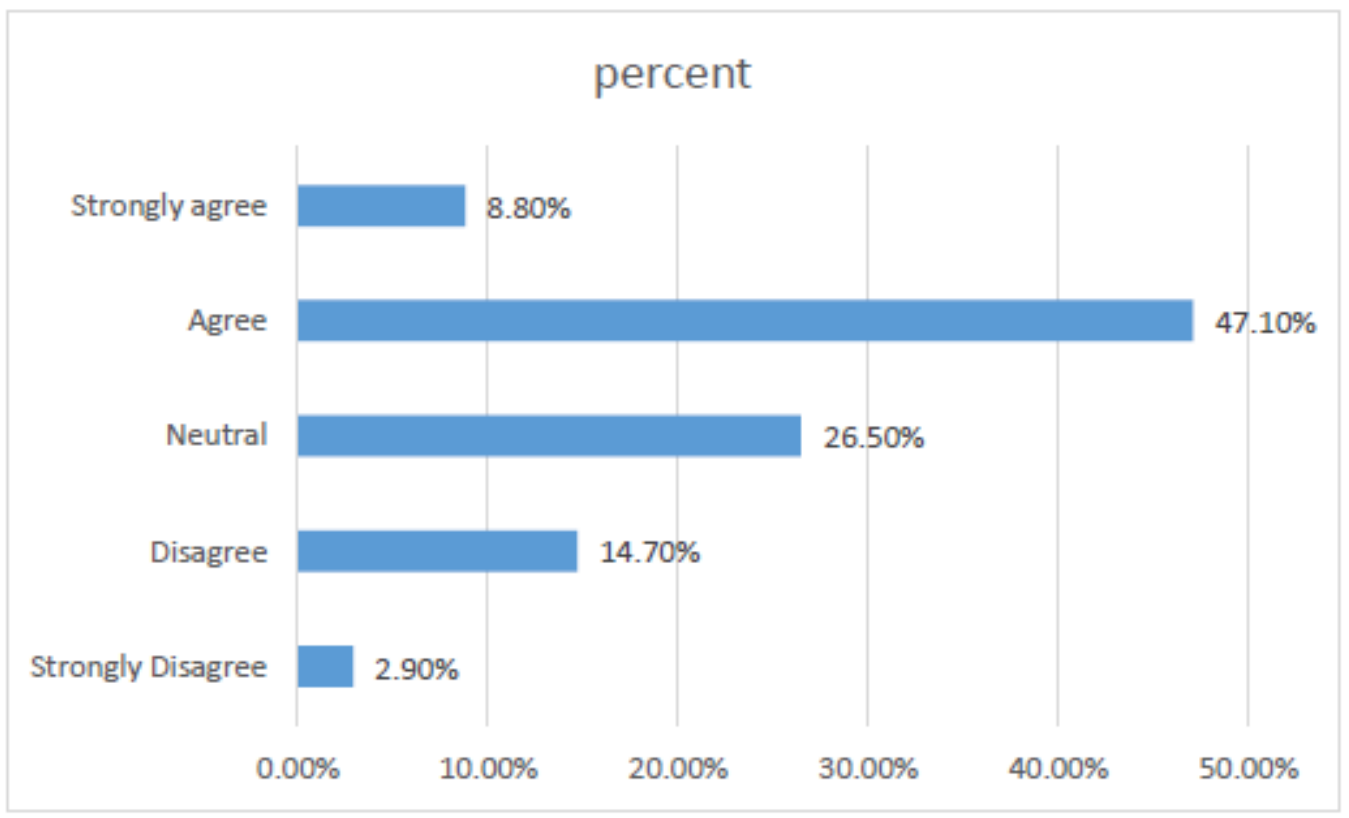

Figure no 3.17: flexible in terms of return and refund policy.

Interpretation: Among all 68 respondents there were $8.80 \%$ respondents who stronglyagreed that Myntra is flexible in terms of return and refund policy, $47.10 \%$ respondents said Agree, $26.50 \%$ said neutral, $14.70 \%$ were disagree and $2.90 \%$ were strongly disagree.

Q18) Does myntra provides scanning feature?

Table no 3.18: myntra provides scanning feature

\begin{tabular}{|l|l|l|}
\hline Scanning Feature & Frequency & Percent \\
\hline Strongly Disagree & 3 & 4.40 \\
\hline Disagree & 7 & 10.30 \\
\hline Neutral & 24 & 35.30 \\
\hline Agree & 32 & 47.10 \\
\hline Strongly Agree & 2 & 2.90 \\
\hline Total & 68 & 100 \\
\hline
\end{tabular}




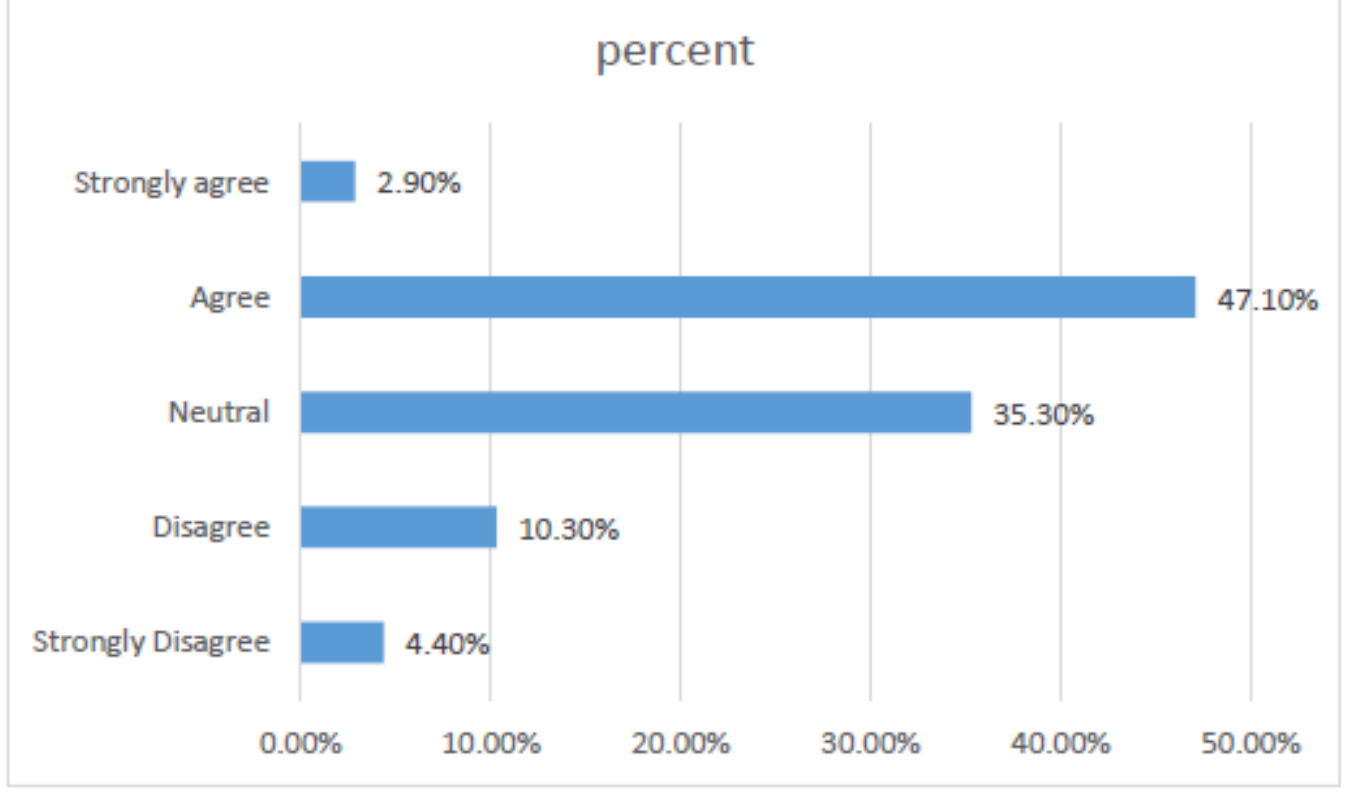

Figure no 3.18: myntra provides scanning feature

Interpretation: Among all 68 respondents there were $2.90 \%$ respondents who stronglyagreed that myntra provides scanning feature, $47.10 \%$ respondents said Agree, $35.30 \%$ said neutral, $10.30 \%$ were disagree and $4.40 \%$ were strongly disagree.

\section{Summary and Conclusions}

\subsection{Findings}

4.1.1 More than 50\% of the consumer are youngsters, according to my data 16-25 age group is the most common group for the people prefer the myntra for online shopping for clothing and body care.

4.1.2 51\% of the consumers are male, so the customer base for myntra are both male and female, now a day's man are equally active in shopping online for clothing and body care and essentials.

4.1.3 $72.10 \%$ of the consumers are students, this study clearly shows that myntra's customer base is strongly dependent on the students and young people for selling their product.

4.1.4 The income of the customer base of the myntra is different, but most of the consumers are from the income level which is less than 2 lakhs.

4.1.5 Most of the consumers of myntra are graduate.myntra focuses on the upcoming generation as their customer base, which helps them in getting more and more customer for their website, 
International Journal of Social Science and Economic Research

ISSN: 2455-8834

Volume:06, Issue:07 "July 2021"

myntra many times adopt target marketing, which helps the company to know more about the base of the most important customer for them.

4.1.6 According to my findings by the survey conducted with different people, $45.60 \%$ of the customer base purchases any product from myntra once in month, but $41.20 \%$ of the customer purchases from myntra only when there is some festival or occasion. myntra also have a customer base which is active for purchases every week.

4.1.7 The area which I have selected, prefers to pay the amount by the method of cash on delivery. Among 68 respondents $55.90 \%$ of them uses cash on delivery.

4.1.8 According to my findings, $27.90 \%$ customers spends more than RS 5000 per year in shopping from myntra.

4.1.9 Myntra has a customer base which can spend from Rs 100 to more than 5000, it shoes that they have everything for every base of the customer. The products they have can be purchased by the rich people of the society to the lower class. It shows that myntra has a wide grasp in the market.

\subsection{Limitations}

4.2.1 The data that has been collected is from a selected area, so we cannot be able to conclude that this finding is absolutely correct.

4.2.2 The data collected concluded that the survey was mainly conducted and filled by the youngsters, it may be possible that if the survey was filled by the people of other age group the results may be different.

4.2.3 There is always a chance that the respondents have not filled the questionnaire by reading it properly.

4.2.4 The research activity is based on complete assumptions because we tend to assume certain important factors which are involved in research and then come up with the conclusion. If we take a look at what we have performed here we will come to know that research is borne to have certain limitations with it. Possibilities prevail that the respondent may not get the question right and he may give wrong answer.

4.2.5 There is a possibility that due to technical issues he may not only get the questionnaire and then the response may not be received only.

\subsection{Suggestions and recommendations}




\section{International Journal of Social Science and Economic Research}

ISSN: $2455-8834$

Volume:06, Issue:07 "July 2021"

4.3.1 The company must connect with the customers for getting the proper review of the product, and the delivery person, which will help the company to construct a relationship between the customer and the company.

4.3.2 The company should improve their return and refund policy which will help them in building the trust factor between the customer and the company.

4.3.3 They should provide discounts for the customer base which can spend Rs. 100-2000 which will give them a opportunity to connect with new customer and also in holding their middle and lower income level customer base.

4.3.4 Currently myntra offer very few or no Loyalty programs for e-consumers which most of the solid stores provide. To maximize customer lifetime value for long term run Loyalty Programs for existing high value e-consumers should be launched.

4.3.5 More of Brand \& trust building exercises should be carried out in order to position a positive image of myntra as online shopping in consumer's mind.

4.3.6 Online shopping services are mostly available in metro cities or in the urban areas for eretailers to expand the customer base in smaller towns they need to do tie ups with small entrepreneurs \& local suppliers.

\subsection{Conclusion}

The main objective of this study is to explore the consumer satisfaction levels on Overall Shopping Experience of myntra. This study helped me in understanding the importance of ecommerce and internet in our daily life, how we can connect with our customer and provides them what product the wants and needs. Due to fast moving lifestyle, online shopping has been growing drastically in India. With developed internet penetration, increasing adoption of devices like smartphones, tablets, and laptops, and access to the Internet and the shift in buying behaviour among the consumers has contributed to the rapid growth of the online consumer base. The increase of online shopping has become a trendy way for consumers to shop over internet. The research indicates that shift in buying behaviour towards online is positive due to reasons like cash on delivery, discounts, schemes \& quality of products offered.

With the help of the questioner I have found that the customer wants different things from a company, but it depends on the company how they will satisfy their customer. But due to limited resources and limited area to conduct a survey this survey can't be applicable for all the customer. As the taste and preferences may be different from place to place, area to area. 
International Journal of Social Science and Economic Research

ISSN: 2455-8834

Volume:06, Issue:07 "July 2021"

Myntra's decision making mostly influenced by marketing influences like the Price, Advertisements on TV, Newspapers \& Magazines, Free samples, Quality of product \& Brand Image impacts most on consumers' willingness to buy online. Overall, most of consumers reported to have satisfied experience with the quality and services offered to them by myntra. Hence the study directs the myntra should focus on these important aspects in order to attract the more customers towards online shopping by their web site and different forms of network to reach more and more customer base.

\section{References}

\section{Articles and journals}

1. Gehrt, K., Rajan, M., Shainesh, G., Czerwinski, D. and O'Brien, M. (2012), "Emergence of online shopping in India: shopping orientation segments", International Journal of Retail \& Distribution Management, Vol. 40 No. 10,pp. 742-758.

2. Jayaprakash. K., Balakrishnan. N and Sivaraj. C (2016) Factors influencing the buying behaviour of online rural consumer in Pollachi Taluk, International Journal of Management and Social Science Research Review, 1 (27), Pp. 1 - 5.

3. Jukariya, T., \&Singhvi, R. (2018). A Study of Factors Affecting Online Buying Behavior of Students. Int. J. Curr. Microbiol. App. Sci, 7(1), Pp.2558-2565.

4. Shanbhog, M., Singh, M., \& Mishra, S. (2016). Study on Customer's attitude towards Online firms based on their Service Reputation.

5. Adrita Goswami et.al, (2013). Customer Satisfaction towards Online Shopping with Special Reference to Teenage Group of Jorhat Town Paripex - Indian Journal of Research, 3(4), Pp-239-241.

6. Syed Shah Alam, Norjaya Mohd. Yasin (2010) Journal of Marketing Development and Competitiveness 5(1), 71-78.

7. Parimal Vyas, Pooja Srinivas (2002) Online buying fact or fiction. Delhi Business Review. Vol. 3, No. 1, January - June.

8. Sinha, Jayendra. University of South Carolina, ProQuest Dissertations Publishing, 2010. 1475736.

9. V.Kumar and Denish Shah, 2011, "Effects of Configuration and ExposureLevels on 
International Journal of Social Science and Economic Research

ISSN: 2455-8834

Volume:06, Issue:07 "July 2021"

10. Responses to Web Advertisements ”, Journal of Advertising Research-June2011

11. T. Shenbhagavadivu, 2015, "A Study on Customer Satisfaction Towards Online Shopping", SUMEDHA Journal of Management, Vol. 4, Issue No:2, June 2015.

\section{Websites}

https://www.myntra.com

https://yourstory.com

https://www.linkedin.com 